\title{
ПІДВИЩЕННЯ ЯКОСТІ ОСВІТИ З ЗАЛУЧЕННЯМ КРЕАТИВНИХ МЕТОДІВ ПРИ ПІДГОТОВЦІ ІНЖЕНЕРІВ ПЕДАГОГІВ
}

2. Hanitkevych, Ya. Yevhen Ozarkevych - odyn iz zacnovnykiv novitnoi ukrainskoi medytsyny (Do 150richchia vid dnia narodzhennia [Yevhen Ozarkevych one of the founders of the newest Ukrainian medicine (To the 150th anniversary of his birth)]. [Elektronic reource].Available at: http://ntsh.org/content/ievgenozarkevich-odin-iz-zacnovnikiv-novitnoyi-ukrayinskoyimedicini-do-150-richchya-vid [in Ukrainian].

3. Hvozdetskyi, T. (1931). Uchast ukrainskykh likariv na zahranychnykh likarskykh kongresakh pered viinoiu [Participation of Ukrainian doctors in foreign medical congresses before the war]. Medicinal Herald, vol. 2-3, pp. 34-38. [in Ukrainian].

4.Hnatiuk, V. (1923). Naukove tovarystvo im. Shevchenka: Z nahody 50-littia yoho zasnuvannia (1873-1923) [Shevchenko Scientific Society: On the occasion of the 50th anniversary of its foundation (18731923) ]. Lviv, NTSh, 170 p. [in Ukrainian].

5. Studynskyi, K. (1928). Naukove tovarystvo im.
Shevchenka u Lvovi (1873-1928) [Shevchenko Scientific Society in Lviv (1873-1928)]. Lviv, 125 p. [in Ukrainian].

6. Rudnytska, A. (1991). Likarska komisiia NTSh [Medical commission of Shevchenko Scientific Society]. Medical collection. New series, vol.1. Lviv, pp. 84-89. [in Ukrainian].

7. Ozarkevych, E. (Ed.). Terminolohichni vytiahy [Terminological excerpts]. Likarskui zbirnyk NTSh, vol. 5, no. 2. 1899 , pp. $1-4$; vol.2, no. 2. Lviv, 1900 , pp. 51-53; vol.3, no. 2. Lviv, 1901, pp. 77-79. [in Ukrainian].

8. Chaikovskyi, M. (1927). Diialnist Matematychnopryrodopysno-likarskoi sektsii ta yii dyrektora redaktora pershykh 25-ty tomiv "Zbirnyka MPLS" dra V.Levytskoho [Activities of the Mathematical and Natural-Drug Section and its director and editor of the first 25 volumes of the "Collection of MPLS" Dr. V. Levytsky]. Collection of MLLS NTSh, vol. 26, pp. 418. [in Ukrainian]

Стаття надійшла до редакції 21.02.2018

УДК 378.147

DOI:

Ігор Гевко, доктор педагогічних наук, дочент, завідувач кафедри комп 'ютерних технологій Тернопільського національного педагогічного університету імені Володимира Гнатюка Мирослав Пагута, кандидат педагогічних наук, доцент, доцент кафедри технологічної та професійної освіти Дрогобицького державного педагогічного університету імені Івана Франка

\section{ПІДВИЩЕННЯ ЯКОСТІ ОСВІТИ З ЗАЛУЧЕННЯМ КРЕАТИВНИХ МЕТОДІВ ПРИ ПІДГОТОВЦІ ІНЖЕНЕРІВ ПЕДАГОГІВ}

У статі розглянуто проблеми підвищення якості освіти при підготовиі інженерів педагогів. Розглянуто основні проблеми якості освіти в Україні. Визначено, що для підвищення якості освіти необхідно залучати креативні методи навчання в освітній процес. В роботі наголошується, щзо підвищення ефективності традиційної системи відбувалося передусім шляхом упровадження нових підходів до методики проведення лекиій, семінарів, практичних занять, зокрема впровадження креативних методів в навчальний процес. Визначено, щзо викладач комп'ютерних технології повинен володіти так званим інноваційним компонентом: педагогічною діагностикою, рефлексією навчання, проектуванням освітніх систем, конструюванням навчального проиесу, шо веде до формування у нього нового педагогічного і технологічного мислення.

Ключові слова: педагогічна освіта, креативні методи, креативна педагогіка, якість освіти, вчитель комп'ютерних технологій, професійна компетентність, ефективність навчання.

Лim. 5.

Ihor Hevko, Doctor of Sciences (Pedagogy), Associate Professor, Head of the Computer Technologies Department

Ternopil Volodymyr Hnatyuk National Pedagogical University Myroslav Pahuta, Ph.D.(Pedagogy), Associate Professor of the Technological and Professional Education Department Drohobych Ivan Franko State Pedagogical University

\section{IMPROVING THE QUALITY OF EDUCATION BY USING THE CREATIVE METHODS IN THE TRAINING OF TEACHERS-ENGINEERS}

The article considers the problems of improving the quality of education in the training of teachersengineers. The main problems of the quality of education in Ukraine are considered. It is determined that in order to improve the quality of education it is necessary to involve the creative methods of teaching in the educational process. The paper notes that the increase of the effectiveness of the traditional system occurs primarily through the introduction of new approaches to the methodology of conducting lectures, seminars, practical exercises, in particular the introduction of creative methods in the educational process. 


\section{ПІДВИЩЕННЯ ЯКОСТІ ОСВІТИ З ЗАЛУЧЕННЯМ КРЕАТИВНИХ МЕТОДІВ ПРИ ПІДГОТОВЦІ ІНЖЕНЕРІВ ПЕДАГОГІВ}

In the article it is considered, that at the stage of high school preparation of the future engineer-teacher it is necessary to promote the formation of the thinking person capable to navigate in the difficult pedagogical situations, to be able to make the right decisions quickly, to have the latest technologies in the field of engineering, that is, to contribute to the formation of the student's creative personality. The training of future specialists leads to optimization of the educational process, the need to use the approaches, which determine the strategy of forming a competent, creative, capable to the creative solution of professional problems of the individual; updating of professional content, professional knowledge, use of various technologies, activation of actions and business relations, which are inherent to the future specialist of different branches of production. It is proved that the teacher's preparation for pedagogical creativity ensures an ability to form and develop the student's creative personality and to the own professional and personal self-development, which is the dominant goal of the professional training. Preparation of a teacher for pedagogical creativity becomes complete, if it is built on the basis of organic unity of general, special and individual. The use of creative methods of the training of future engineer educators in the field of computer technology is aimed at improving the quality of their readiness for professional activity. In the work it is determined that the teacher of computer technology must have the so-called innovative component: the pedagogical diagnostics, the reflection of teaching, the design of educational systems, the design of the educational process leading to the formation of new pedagogical and technological thinking.

Keywords: pedagogical education, the quality of education, the creative methods, creative pedagogy, a teacher of computer technologies, professional competence, an efficiency of teaching.

П остановка проблеми у загальному вигляді та її зв'язок із важливими науковими чи практичними завданнями. Зміни, що відбуваються в освітній політиці, впливають на характер професійної діяльності педагогів. Сучасний етап розвитку освіти характеризується постійним збільшенням вимог до їі якості, до відповідності освітніх результатів запитам сучасного суспільства. Основним критерієм оцінки якості освіти стає формування мобільної, різнобічно розвиненої особистості, здатної адаптуватися до соціальноекономічних змін та успішно реалізовуватися в умовах інформатизації суспільства.

В умовах посиленого росту об'єму інформації, що поступає, через швидкі зміни в інформаційному світі, певні знання швидко “старіють” і стають непридатними для прогресивного застосування. В суспільстві виникає потреба в особистостях, здатних до самореалізації, до саморозвитку, в людях, які мають нестандартне мислення, які можугь внести нову якість у соціальне і виробниче життя, у культуру народу. Тому проблема пошуку i навчання обдарованих дітей викликає гострий інтерес.

Аналіз останніх досліджень та публікацій. 3 розвитком досліджень проблеми обдарованості опора тільки на інтелект особистості почала суперечити реальним отримуваним результатам. По-перше, послідовники А. Біне, критикуючи прибічників асоціативної психології за уявлення про інтелектуальну діяльність як діяльність репродуктивну, самі також не спромоглися подолати цей недолік при створенні численних тестових завдань на визначення рівня інтелекту (Л. Терман, Дж. Равен, Р. Кеттелл та інші). Практично всі завдання тестів мають конвергентний характер. По-друге, проблеми у розробці “штучного інтелекту" перших примітивних ЕОМ, які розв' язували завдання за жорстко завданим алгоритмом і не були спроможними вирішити жодного творчого завдання, виявили і сугтєві недоліки у теорії та практиці дослідження інтелекту. Нарешті тривале лонгітюдне дослідження Л. Термана у школах США і спостереження за сотнями обдарованих людей дозволило зробити висновок, що для досягнення видатних результатів у різних сферах діяльності часто потрібен не високий інтелект у його тодішньому розумінні (тобто не те, що вимірюється за допомогою IQ), а якась інша складна якісна своєрідність психіки особистості - здатність генерувати нові, оригінальні ідеї, знаходити нетрадиційні способи розв'язування проблемних задач. Ця якість була визначена на початку 50 -х років XX століття як "креативність". Саме креативність (здатність до творчості) похитнула монополію поняття “інтелект” у розумінні такої особистісної характеристики, як обдарованість [3, 193].

Аналіз досліджень і публікацій в яких започатковано розв'язання даної проблеми показав що наукове обгрунтування сутності креативності було здійснено психологами (Д. Векслер, Дж. Гілфорд, Г. Грубер, Р. Кеттел тощо).

Наукові дослідження присвячені формуванню креативності проводили відомі педагоги Н. Вишнякова, Т Галич, Н. Мойсеюк, Л. Романишина, Т. Сидорчук, С. Сисоєва, М. Сметанський, Л. Тарасенко, В. Фрицюк, І. Шахіна, В. Шинкаренко та ін. Дані дослідження дають нам грунтовну підставу вважати що визначальною якістю творчої особистості $є$ креативність, яка 3 одного боку виступає важливою характеристикою діяльності 


\section{ПІДВИЩЕННЯ ЯКОСТІ ОСВІТИ З ЗАЛУЧЕННЯМ КРЕАТИВНИХ МЕТОДІВ ПРИ ПІДОТОВЦІ ІНЖЕНЕРІВ ПЕДАГОГІВ}

умовою і їі результатом, а 3 іншого - це цілісна особистісна якість, яка виступає системоугворюючою ланкою в структурі професіоналізму вчителя.

Формулювання мети статті. Визначити шляхи підвищення якості освіти сучасного вчителя, зокрема інженерів педагогів за допомогою залучення різних підходів та методів, зокрема креативних.

Виклад основного матеріалу. На сьогодні інженерно-педагогічні працівники мають стати основною рушійною силою відродження та створення якісно нової національної системи професійно-технічної освіти. У зв'язку з цим головна увага має бути зосереджена на підвищенні професійної кваліфікації інженерівпедагогів. Виходячи 3 цього, на етапі вузівської підготовки майбутнього інженера-педагога слід сприяти формуванню мислячої людини, здатної орієнтуватися в складних педагогічних ситуаціях, вміти швидко приймати правильні рішення, володіти новітніми технологіями в галузі інженерії, тобто сприяти формуванню творчої особистості студента.

Аналіз наукової літератури дозволяє констатувати необхідність оптимізації професійної підготовки майбутніх інженерівпедагогів шляхом пошуку нових дидактичних підходів до іiі організації. Підготовка майбутніх фахівців зумовлює оптимізацію освітнього процесу, потребу використання підходів, що зумовлює стратегію формування компетентної, креативної, здатної до творчого вирішення професійних проблем особистості; оновлення професійного змісту, професійних знань, використання різноманітних технологій, активізації дій і ділових стосунків, які властиві майбутньому фахівцю різних галузей виробництва. Потреба в новому підході до професійної підготовки зумовлює необхідність його теоретичного обгрунтування й реалізації в педагогічній практиці.

Термін “креативність” у педагогіці та психології набув поширення на заході у 60-ті роки ХХ століття після публікацій робіт Дж. Гілфорда, завдяки яким фактично народжується сучасна психологія творчої обдарованості (психологія креативності). Досліджуючи інтелектуальні здібності людини, структуру ii інтелекту, Дж. Гілфорд виділив два базові типи мислення: дивергентний і конвергентний. Конвергентне мислення спрямоване на аналіз всіх наявних способів розв'язання задачі, з тим, щоб вибрати 3 них єдиний правильний. Конвергентне мислення - логічне, послідовне односпрямоване мислення, виявляється в процесі розв'язання завдань, які мають єдину правильну відповідь. Конвергентне мислення лежить в основі інтелекту. Дивергентне мислення - це мислення, “що йде одночасно у багатьох напрямках”, воно спрямоване на те, щоб породити безліч різних варіантів розв'язання задачі [3, 257]. Це альтернативне, алогічне мислення, що виявляється в процесі розв'язання завдань, шо припускають існування безлічі правильних відповідей. Дивергентний тип мислення Дж. Гілфорд пов'язав із породженням, продукуванням багатьох рішень проблемної ситуації на основі однозначних вихідних даних, вважаючи, що саме він $\epsilon$ “серцевиною”, “ядром” творчої обдарованості, креативності. За Дж. Гілфордом, дивергентне мислення характеризується такими особливостями:

- легкість і продуктивність - тобто наскільки швидко індивід може створювати певні продукти творчості (ідеї, думки, об'єкти тощо);

- гнучкість - здатність швидко переключатися 3 однієї проблеми на іншу або об'єднувати їх;

- оригінальність - своєрідність мислення, незвичний підхід до проблеми, ії нове вирішення;

- точність (відповідність) - стрункість розумових операцій щодо тієї чи іншої проблеми, вибір рішення, адекватного поставленій меті.

Спочатку Дж. Гілфорд виділив чотири основні параметри творчої обдарованості:

1) оригінальність - спроможність продукувати віддалені асоціації, незвичні відповіді;

2) семантичну гнучкість - здатність виділяти функцію об'єкта і пропонувати його нове застосування;

$3)$ семантичну спонтанну гнучкість спроможність продукувати різноманітні ідеї в нерегламентованій ситуації;

4) образну адаптивну гнучкість - спроможність змінювати форму відображуваного стимулу таким чином, щоб виявити в ньому нові ознаки й можливості для використання,

Згодом Дж. Гілфорд робить висновок, що креативність характеризується шістьма основними параметрами:

1) здатністю до виявлення й формулювання проблем;

2) здатністю до генерування великої кількості ідей;

3) гнучкістю - здатністю до продукування найрізноманітніших думок;

4) оригінальністю - здатністю відповідати на подразники нестандартним способом;

5) здатністю вдосконалювати об'єкт сприймання, додаючи певні деталі;

6) здатністю розв'язувати проблеми шляхом 


\section{ПІДВИЩЕННЯ ЯКОСТІ ОСВІТИ З ЗАЛУЧЕННЯМ КРЕАТИВНИХ МЕТОДІВ ПРИ ПІДГОТОВЦІ ІНЖЕНЕРІВ ПЕДАГОГІВ}

реалізації відповідних аналітико-синтетичних операцій $[4,25]$.

Дослідженням проблем продуктивного мислення у західноєвропейській та американській психології займалися Дж. Гілфорд, В. Келлер, Н. Майер, П. Торранс, В. Франкл, Е. Фром та інші, у вітчизняній психології цей напрямок представлений у працях О. Брушлинського, 3. Калмикової, Б. Кедрова, Я. Пономарьова, C. Рубінштейна та багатьох інших. За сучасних умов поняття “креативність” активно використовується в дослідженнях вітчизняних та зарубіжних авторів (В. Дружинін, Л. СрмолаєваТоміна, М. Козленко, М. Лещенко, О. Лук, А. Маслоу, О. Матюшкін, В. Моляко, В. Пєтухов, К. Тошина та ін.) $[2,98]$. Однак, як зазначає Р. Павлюк, згадане поняття не можна визнати чітко та однозначно визначеним, не запропоновано єдиного підходу або концепції креативності. Тільки в зарубіжній психології існує близько сотні визначень згаданого поняття, що відбивають уявлення дослідників, представлених в межах численних концепцій креативності [5].

Забезпечення творчого розвитку особистості - найважливіше завдання всіх світових освітніх систем. Один із головних напрямів гуманізації освіти є спрямування навчального процесу на формування, розвиток і саморозвиток суб'єктів педагогічної взаємодії. Важливість цієї тези підкреслюється в усіх документах про освіту нашої держави, а в Державній національній програмі “Освіта" (“Україна ХХІ століття”) одним із стратегічних завдань окреслено створення умов для формування освіченої, творчої особистості громадянина, реалізації та самореалізації його природних задатків і можливостей в освітньому процесі. Василь Олександрович Сухомлинський підкреслював, що особистість дитини - більше результат саморозвитку, ніж регульованого розвитку, що психологічним механізмом сприяння цьому саморозвитку є психічний стан злиття впливу дорослого і самоактивності дитини 3 переважанням останньої. Це твердження вірне для всіх суб'єктів педагогічної взаємодії. Саме тому тільки такі психолого-педагогічні концепції, які пропонують суб'єктам педагогічного процесу психолого-педагогічні механізми самовдосконалення та прилучення до творчого процесу, особистісної самореалізації, можуть вважатись гуманістичними, незалежно від наявності чи відсутності в них цієї назви. За таких умов загальнопедагогічна підготовка викладача будь-якого навчального закладу і, зокрема вчителя, набуває ефективності, якщо іiі зміст, форми й методи відображають специфіку процесу формування творчої особистості, враховують закономірності протікання творчого процесу в конкретних умовах професійної діяльності [2, 78].

Підготовка вчителя до педагогічної творчості забезпечує його здатність як до формування та розвитку творчої особистості учня, так і до власного професійного та особистісного саморозвитку, що $є$ домінуючими цілями його професійної підготовки. Підготовка вчителя до педагогічної творчості набуває завершеності, якщо будується на основі органічної єдності загального, особливого та індивідуального. Як загальне - вона $\epsilon$ складовою професійної загальнопедагогічної підготовки вчителя; як особливе - має свою специфіку, зумовлену особливостями й закономірностями творчого процесу і формування творчої особистості; як індивідуальне відображає залежність підготовки від особистісних якостей учителя $[1,95]$.

У науковій літературі креативна педагогічна діяльність розглядається також як творчий підхід до вирішення проблеми педагогічного процесу, в ході якого інтереси й цінності особистості є домінуючим компонентом організації та сенсу навчальної діяльності, тобто, креативний підхід до навчальної проблеми передбачає не розв'язання готових дидактичних задач, а генерацію, творче формулювання й розробку ідей, задумів та проектів у навчальному процесі. Особливостями креативної педагогічної діяльності $є$ те - що вона визначає стосунки між викладачем і студентом як партнерські, а основним елементом навчального процесу виступають не знання, а інформація. При цьому студент не засвоює готові уявлення і поняття, а сам з різноманітних одиниць інформації видобуває власне уявлення про оточуюче середовище.

Система креативної технологічної освіти спрямована на формування творчого мислення всіх студентів, розвиток їх інтелектуальних здібностей які мають першорядне значення для оволодіння знаннями і вміннями в різних галузях науки. Креативна освіта перетворює засвоєння знань студентів на захоплюючу мандрівку, пригоду, яка пов'язана 3 розкриттям секретів комп'ютерної техніки та програмування. Практичну цінність, значущість здобутих у дослідженнях знань студенти усвідомлюють, застосовуючи їх для проектування технологій програмування.

Креативна педагогіка включає:

1. Позитивний емоційний зміст навчального процесу (Творчий процес можливий лише в умовах позитивного емоційно-інтелектуального натхнення). 


\section{ПІДВИЩЕННЯ ЯКОСТІ ОСВІТИ З ЗАЛУЧЕННЯМ КРЕАТИВНИХ МЕТОДІВ ПРИ ПІДГОТОВЦІ ІНЖЕНЕРІВ ПЕДАГОГІВ}

2. Критичне ставлення до стереотипів, до установлених норм. "Творчість починається 3 сумніву".

3. Пошук варіативних рішень будь-якої проблеми.

4. Використання методу відкритого питання. (Дуже ефективно розвиває творчий потенціал студентів, пошук відповіді на запитання, навіть, якщо не буде знайдена відповідь, але розвиваючим $є$ сам процес пошуку).

5. Винахідницька діяльність (Не обов'язково чогось нового. Навіть якщо це “свій велосипед”).

Студент разом з викладачем самовіддано грає - грає всерйоз у науку, в авторів винаходів, у наукових доповідачів, опонентів, рецензентів [1, 274].

Технологія формування креативності досить складна. В ній можна виділити кілька етапів:

1. Визначення рівня креативності кожного студента.

2. Визначення перспектив розвитку креативності та врахування індивідуальних особливостей студентів.

3. Розробка системи знань спрямованих на розвиток креативності.

4. Організація творчої діяльності студентів.

Виявляється, що навчити творчості взагалі до успіху не веде. Тому необхідна система роботи i перш за все вивчення особистості студента.

Помічено, що креативна (творча) якість проявляється в комплексі зі станом здоров'я, нервової системи, характеру, здібністю до незвичайних рішень та вчинків.

Висновок. У ситуації вільного вибору навчальних завдань і способів їх виконання прагнення усвідомити потребу в нестандартному вирішенні пізнавальних завдань проявляється компетентність особистості, виробляються необхідні майбутньому фахівцю компетенції. У ході виконання різних видів навчальної роботи: складання плану-конспекту, опорних схем, таблиць, алгоритмів дій активізується розумова діяльність майбутніх інженерів-педагогів у галузі комп'ютерних технологій галузі, що забезпечує продуктивну реалізацію структурних компонентів пізнавальної діяльності. Використання креативних методів до підготовки майбутніх інженерів-педагогів у галузі комп'ютерних технологій спрямований на підвищення якості їх готовності до професійної діяльності.

\section{ЛІТЕРАТУРА}

1. Антонова О. С. Теоретичні та методичні засади навчання педагогічно обдарованих студентів: монографія/ О. С. Антонова// Житомир: Вид-во ЖДУ, 2007. - 472 с.

2. Гевко I. В. Формування i розвиток професіоналізму вчителя технологій: теорія $\mathrm{i}$ методика: монографія/ I. В. Гевко// -. Кам'янецьПодільський: Аксіома, 2017. - 392 с.

3. Дичківська I. М. Інноваційні педагогічні технології / І. М. Дичківська// - К. : Академвидав, 2004. $-352 \mathrm{c}$.

4. Савенков А. И. Основные подходы к разработке концепции одарённости / А. И Савенков // Педагогика. - М., 1998. - № 3. - C. 24-29.

5. Павлюк Р. О. Креативність як складова частина професійної підготовки майбутніх учителів [Електронний ресурс]. Режим доступу: http://www.rusnauka.com/16_NPM_2007/ Pedagogica/22154.doc.htm.

\section{REFERENCES}

1. Antonova, O. Ye. (2007). Teoretychni ta metodychni zasady navchannya pedagogichno obdarovanyx studentiv: monografiya [Theoretical and methodological principles of teaching pedagogically gifted students]. Zhytomyr: ZHDU, 472 p. [in Ukrainian].

2. Hevko, I. V. (2017). Formuvannya i rozvytok profesionalizmu vchytelya texnologij: teoriya $i$ metodyka [Formation and development of the professionalism of the teacher of technologies: theory and methodology]. Kamyanets-Podilsky: Axiom, 392 p. [in Ukrainian].

3. Dychkivska, I. M. (2004). Innovacijni pedagogichni texnologiyi [Innovative pedagogical technologies]. Kyiv: Academic Edition, 352 p. [in Ukrainian].

4. Savenkov, A. I. (1998). Osnovnyye podkhody $k$ razrabotke kontseptsii odarennosti [Basic approaches to the development of the concept of giftedness]. Pedagogy. Moscov, no.3, pp. 24-29.[ in Russian].

5. Pavlyuk, R. O. Kreatyvnist yak skladova chastyna profesiynoyi pidhotovky maybutnikh uchyteliv [Creativity as an integral part of future teacher training]. Available at:http:// www.rusnauka.com/16_NPM_2007/Pedagogica/ 22154.doc.htm [in Ukrainian].

Стаття надійшла до редакції 21.02.2018

\section{G58080

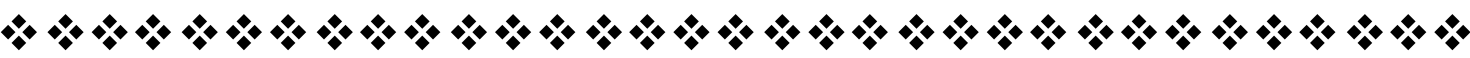

